\title{
BUDGET SURPLUS MANAGEMENT AND FISCAL "FINE TUNING”
}

\author{
Mstislav P. Afanasiev \\ Doctor of Economics, Professor of Public Finance, \\ Politics and Governance Department National \\ Research University - Higher School of Economics (HSE); \\ Chief research fellow, Institute for economic forecasting, \\ Russian Academy of Sciences. \\ Address: HSE, 20 Myasnitskaya Street, 101000, Russian Federation. \\ E-mail: mstafan@hse.ru; mstafan@gmail.com \\ ORCID 000288739402

\section{Natalia N. Shash} \\ Doctor of Economics, Professor of Financial Management, Financial \\ Management Department, Plekhanov Russian University of Economics. \\ Address: 36 Stremyanny Lane, 117997, Moscow, Russian Federation. \\ E-mail: SHash.NN@rea.ru
}

\begin{abstract}
The subject of research of this paper is the specifics of forming and managing a budget surplus when providing economic growth for the national economy. The results of analyzing the concepts of a budget balance are presented, and directions for managing a positive balance of the state budget are revealed. The specifics of the macroeconomic politics of a surplus are given, and it is revealed that forming a "new" fiscal regime - surplus regime - requires a radical restructuring of budget management. The general typical features of countries with a long-term period of a budget surplus are revealed: focus on budget consolidation on the expenditure side of the budget and the ensuing complex budget reforms made after achieving a surplus. It is discovered that one of the main reasons for supporting a stable surplus budget in a number of the world's countries is the radical restructuring of economic and financial priorities, which was caused by serious macroeconomic shocks. It is noted that when assessing the possibility of maintaining a budget surplus in specific countries, it should be taken into account that unfavorable macroeconomic events such as the financial crisis of 2008 or the global pandemic of COVID-19 in the current year (2020) are of crucial significance for maintaining a surplus. According to the results of a comparative analysis of the dynamics of the level of budget deficit and the rates of economic growth, using the example of Switzerland and Norway for 2009-2019, no direct correlation between these indicators was discovered, and it was concluded that there was a lack of empirical evidence and appropriate theoretical generalizations about the existence of a cause-and-effect relationship between economic growth and the type of balance (deficit, surplus, "zero-based") of the state budget. The advisability of using the budget surplus to reduce the tax burden and to reduce the level of state debt was assessed.
\end{abstract}


Keywords: budget balance; budget management; budget deficit and surplus; theory of "tax smoothing"; budget policy; fiscal regime; economic growth; money hoarding.

Citation: Afanasiev, M. P. \& Shash, N. N. (2020). Budget Surplus Management and Fiscal "Fine Tuning”. Public Administration Issues, no 6 (Special Issue II, electronic edition), pp. 84-97 (in English), DOI: 10.17323/1999-5431-2020-0-6-84-97.

\section{Main concepts for managing the budget balance}

The stable budget deficit in an overwhelming majority of countries in the world piqued the interest of economists in the theories and facts relating to the reasons for forming a budget policy. The most developed is the theory of budget balance, which is in fact a theory of budget deficit. The problem of a balanced budget has received wide coverage. It is especially worth mentioning the publications of English and American economists.

First and foremost, when looking back, it is worth paying attention to the position of neo-Ricardians, for example, the famous A.C. Pigou $(1928,1960)$ who, in his research on state finances, touched on this problem, including his ideas of negative externalities and the need for taxation specifically for the investment needs of the national economy.

The classic summary paper by R. Barro (1989) on standard models of budget deficit holds an important place among such research.

It is interesting to remember the position of neo-Keynesian macroeconomics on budget deficits, for example, the thoughts of J. Stiglitz. In particular, Stiglitz (2010) wrote that when a government is at a deficit, private savings Sp serve two functions: to finance the government deficit $(\mathrm{G}-\mathrm{T})$ and finance investments (I):

$$
\mathrm{Sp}=\mathrm{I}+(\mathrm{G}-\mathrm{P})
$$

Likewise, at the same time it can be considered that a deficit corresponds to negative private savings:

$$
\mathrm{G}-\mathrm{T}=-\mathrm{Sg}
$$

As a result, the first equation can be rewritten in the following form:

$$
\mathrm{Sp}=\mathrm{I}-\mathrm{Sg} \text { or } \mathrm{Sp}+\mathrm{Sg}=\mathrm{I}
$$

The left side of the equality is equal to national savings, i.e., the sum of private savings (households and businesses) and state savings (state). When the capital market is in equilibrium in a closed economy, the national savings are equal to investments (Stiglitz et al., 2010).

The process of budget balancing is thoroughly analyzed in a significant number of sources dedicated to problems of fiscal consolidation (Alesina, Ardagna, 2009; Guichard et al., 2007; Wagschal, Wenzelburger, 2008). 
At the same time, no theory has yet to be formed in economics for an "optimal" budget balance, unlike the repeatedly and deeply developed concept of "optimal taxation".

Due to this, it is quite natural that the most discussed questions in academic circles are those relating to the critical, high level of budget deficit, state debt ceiling, and other crisis aspects in the area of state finances.

Traditionally, most economists continue to follow the example of Buchanan (Buchanan, Wagner, 1977) and consider budget surpluses as an empirical, improbable event, and - in the case of a recorded surplus - as unimportant in terms of theory. Furthermore, this (traditional) approach can be theoretically justified, since a surplus is often seen as a "negative example" (Emigh, 1997), which contradicts the prevailing theory of a fiscal (budget) policy.

However, as the real budget practice of various countries shows, for example in Norway and Switzerland, a budget surplus, contrary to popular belief, is far more common. Thus, for example, the Swiss state budget was formed with a surplus even during a weak state of affairs (fig. 1).

\section{Figure 1: Dynamics of the budget surplus of Switzerland and Norway for 2009-2019', \% of GDP}

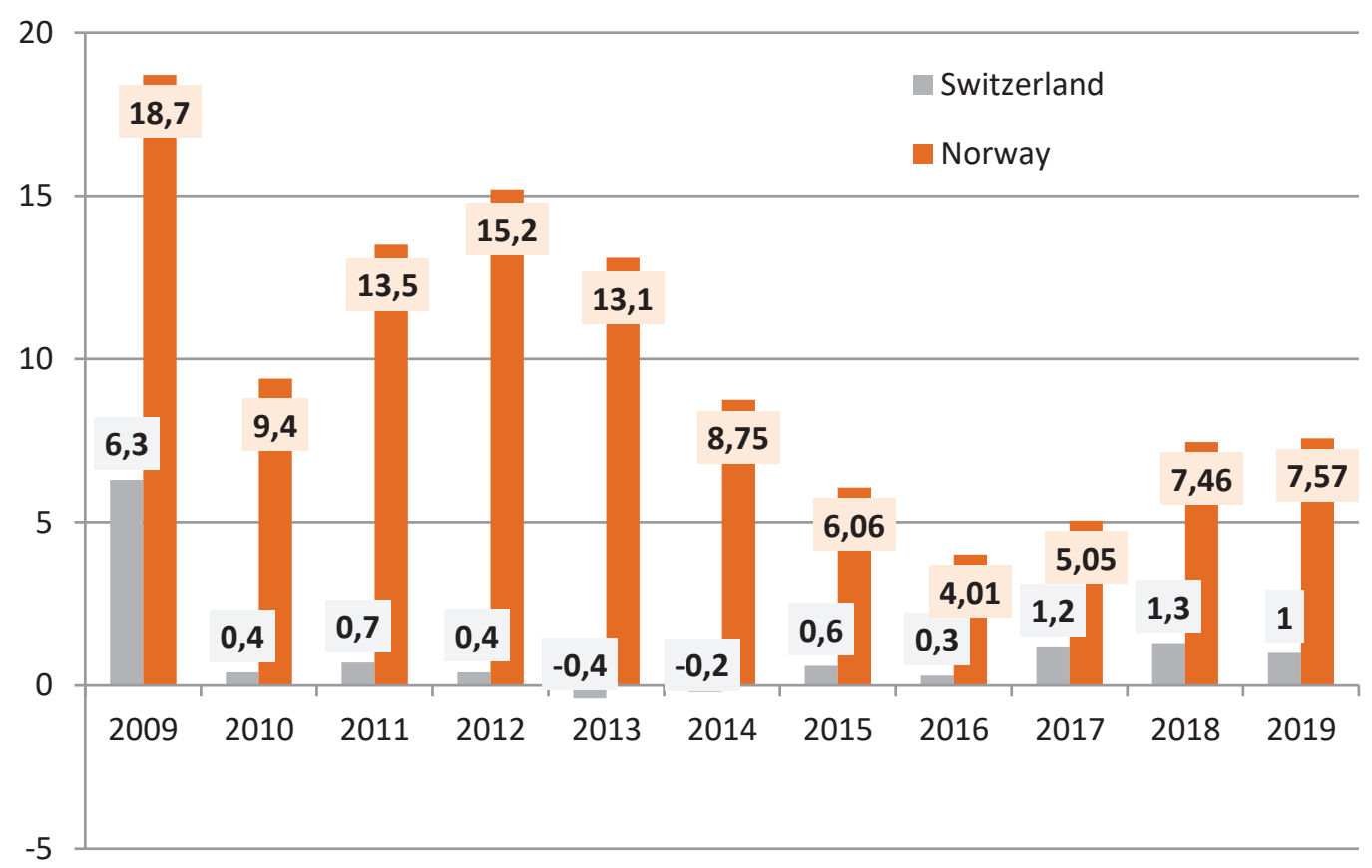

Source: URL: https://www.efd.admin.ch/efd/de/ and https://www.regjeringen.no/no/id4/ (accessed: 13 July 2020).

In connection to this, of undoubtable interest is the work of Haffert (2015), who used material from 13 countries of the OECD (Australia, Canada, Denmark,

\footnotetext{
1 A surplus budget was also planned in these countries for 2020 ( $0.4 \%$ in Switzerland and 7.25\% in Norway); however, the pandemic situation brought significant adjustments to these plans.
} 
Finland, New Zealand, Sweden, and others) over a 30-year period and identified at least 18 periods of a surplus, whereby in some of them, the periods of a budget surplus were recorded at least twice.

The author shows that the identified periods of a "budget surplus" are characterized by varying lengths. Out of the 18 identified "surplus" periods, 6 lasted more than 10 years (on average 11.3). It is these long periods of a budget surplus which seriously conflict with the concept of a deficit. The research mentioned above shows that most of the analyzed countries were able to maintain a budget surplus until the 2008 crisis. The rest of the economies showed shorter periods (from 3 to 5 years) of a budget surplus, which overall aligned with peaks in the global business cycle.

According to the theory of "tax smoothing" (Barro, 1979; Lucas et al., 1983), a budget balance should be used as a buffer, allowing tax rates to be more or less constant, and the budget surplus should be the norm, both during expansion and in times of temporarily low government spending.

At the same time, the question arises of why in some countries balanced budgets turn into surpluses while in others they do not? Thus, in several countries the cases of a budget surplus are a completely extraordinary occurrence, while in others, significantly long periods of a recorded surplus of the state budget are observed.

In many countries, the existence of a budget surplus was not accompanied by a fundamental restructuring of fiscal interests. Their fiscal policy remained similar to the policy of countries with a deficit budget. Similarly, the political surplus economy in many respects is akin to the political deficit economy.

At the same time, an analysis of existing sources dedicated to this problem showed that, with consideration of real budget practice and the appearance of a "new" fiscal regime - surplus regime - questions of forming and implementing a modern budget policy in countries around the world should be given the most serious and consistent attention.

\section{Creating and managing a "new" fiscal regime}

In most countries, for example, Japan (1988-1992), Denmark (1986-1989), Great Britain (1999-2001), USA (1998-2000), a budget surplus is only recorded over a very short period (as a rule not exceeding 3-5 years). However, when researching budget surpluses, countries with longer surplus periods should be included in the analysis.

In order to exclude one-time effects, it is advisable to maintain the position supported by Haffert (2015), for example, who defines a "surplus period" as a period of at least two years of an uninterrupted surplus, which is broken by no more than two years of a budget deficit before the budget again returns to a surplus.

One of the factors influencing the length of the budget surplus period (clearly) was the harsh budget reaction to unfavorable macroeconomic events. Countries where long budget surpluses are recorded (for example, New Zealand - 15 years; Canada, Finland, Sweden - at 11 years; Australia, Denmark - at 10 years), experienced serious crises which led to drastic changes to their economic and financial 
priorities. The condition of state finances in these countries demonstrated that the short-term adjustments to the budget policy in the post-crisis period were not sufficient: fundamental reforms were necessary (Lewis, 2003; Mehrtens, 2014). Such reforms not only fought the deficit but also created a new stable context for a budget policy in which a surplus policy was subsequently carried out.

Thus, the analysis shows that a "new" fiscal regime (a "surplus" regime) was created as a result of serious macroeconomic shocks occurring, for example, the deep financial crisis, accompanied in these countries by a loss of trust in the financial markets, which was followed by a consolidation of budget spending.

Some authors believe that an analysis of the reasons for choosing a budget (fiscal) policy of different countries should be conducted from the point of view of the historical and institutional perspectives of their development (Androniceanu et al., 2019; Dadashev, 2017; Serkov, 2017), of the structure of fiscal autonomy of regions inside the countries (Alibegovich et al., 2019). In particular, it was discovered that the interests of the dominant political elite significantly influence the choice of budget policy vector (Schwartz, 1994). At the same time, the deep financial crisis and the subsequent consolidation of spending led to the creation of a new "surplus regime", within which the budget policy was restructured according to the goals of achieving a balanced budget and reducing the level of taxes.

The existence of a budget surplus in various countries of the world gives rise to (at least) three important research questions: how is a surplus created, how is it maintained, and how is it spent. Here, the most important question should be considered that of maintaining a surplus (Alesina et al., 2019).

While the occurrence of a surplus is a question of changing the policy - how can the fiscal policy be changed in order to overcome a deficit? - preserving a surplus is related to the problem of the stability of this policy, i.e., how can it be prevented from changing back?

The question of stability is especially significant since many observers believe that the success of budget consolidation is under the constant threat of "consolidation fatigue" (Von Hagen et al., 2002). Far less is known about stability, however, since most sources primarily examine the process of consolidation itself and pay no attention to its effects.

First, countries in which a long-term budget surplus is observed (over an average of 10 years) experienced unique financial and macroeconomic difficulties, reacting to them by implementing large-scale government investment programs. These investments, however, did not give the expected results but instead exhausted the fiscal possibilities of the government even more.

Second, budget consolidation in countries with a long-term surplus was almost completely concentrated on the spending side of the budget, while countries with a short period of budget surplus relied far more on increasing revenue.

Third, unlike countries with a short-term surplus period, countries with a longterm surplus passed a large number of reforms, particularly, four types of budget rules (Budina et al., 2012), specifically, the budget balance rules (BBR), debt rules (DR), expenditure rules (ER) and revenue rules (RR).

Lastly, at the same time, budget reforms were approved only after reaching a surplus, while in countries with a short-term budget surplus, they usually pre- 
ceded the surplus. This suggests that institutional reforms were not an exogenous cause for changing the fiscal policy, but instead one of its key endogenous elements.

Certainly, while assessing the possibility of preserving a budget surplus in specific countries, it should be taken into account that unfavorable macroeconomic events such as, for example, the 2008 financial crisis or the global pandemic of COVID-19 in the current year (2020), have a crucial impact on preserving a surplus.

\section{Managing a surplus in the interests of economic growth}

In Norway and Switzerland the current surplus was achieved thanks to the combination of an exceptionally strong economy, low interest rates and a significant reduction of the defense budget (as a share of the GDP). The increase of social benefits was not stopped. Despite the favorable condition of the government finances of Switzerland, C. Tille (2019), for example, believes that the policy currently being implemented for maintaining a surplus and eliminating debt is ineffective.

The efforts of countries with a recorded budget surplus in the area of budget consolidation based on spending were also connected to a change in the growth model of the respective economies (Cohen-Setton et al., 2019). At the same time, the conducted analysis shows that "surplus" economies can demonstrate very modest indicators of economic growth. As an example, one can compare the size of the budget surplus and the growth rates of Norway and Switzerland for the period from 2009 to 2019 (fig. 2 and fig. 3).

\section{Figure 2: Dynamics of the economic growth rates and budget surplus of Switzerland for 2009-2019}

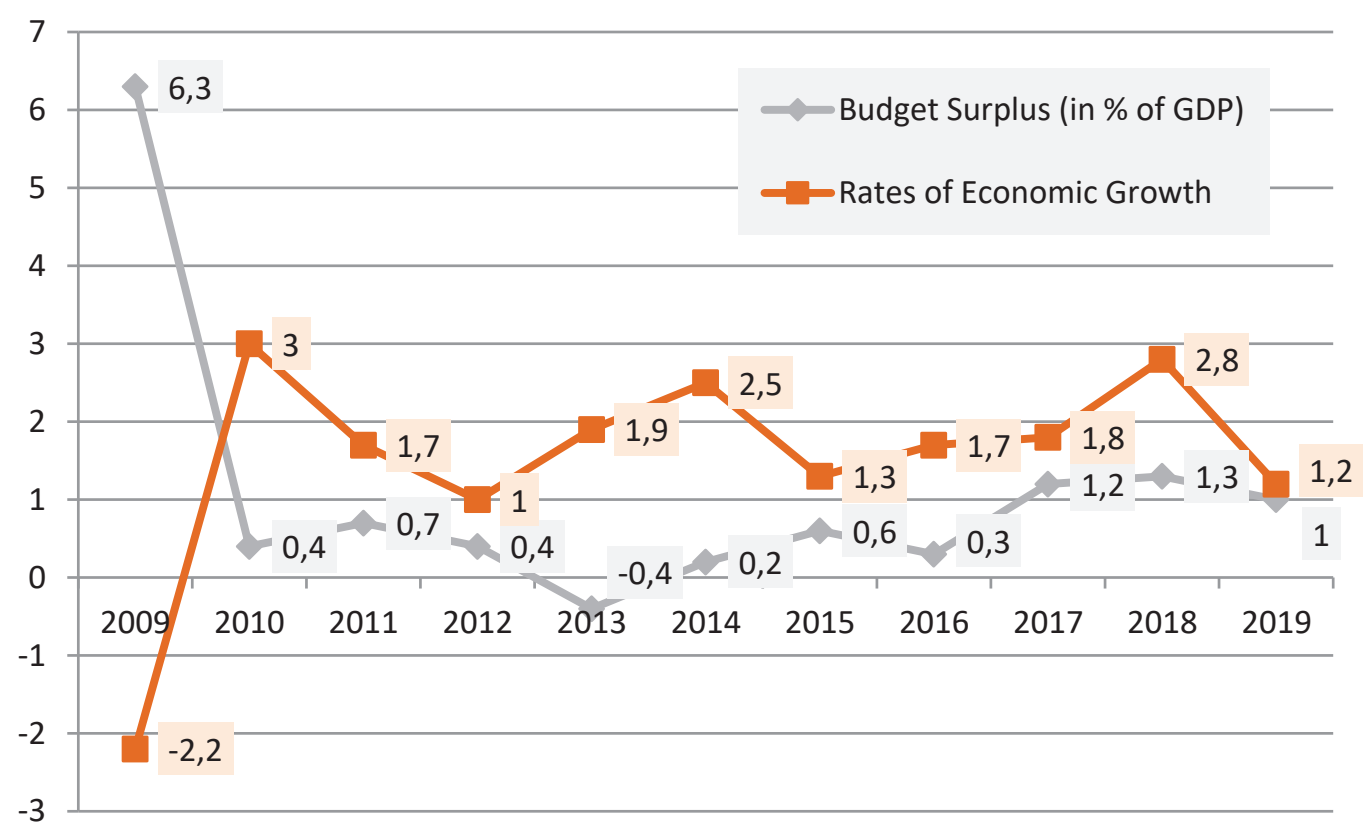

Source: Built on data from https://www.efd.admin.ch/efd/de/ (accessed: 13 July 2020). 


\section{Figure 3: Dynamics of the economic growth rates and budget surplus of Norway for 2009-2019}

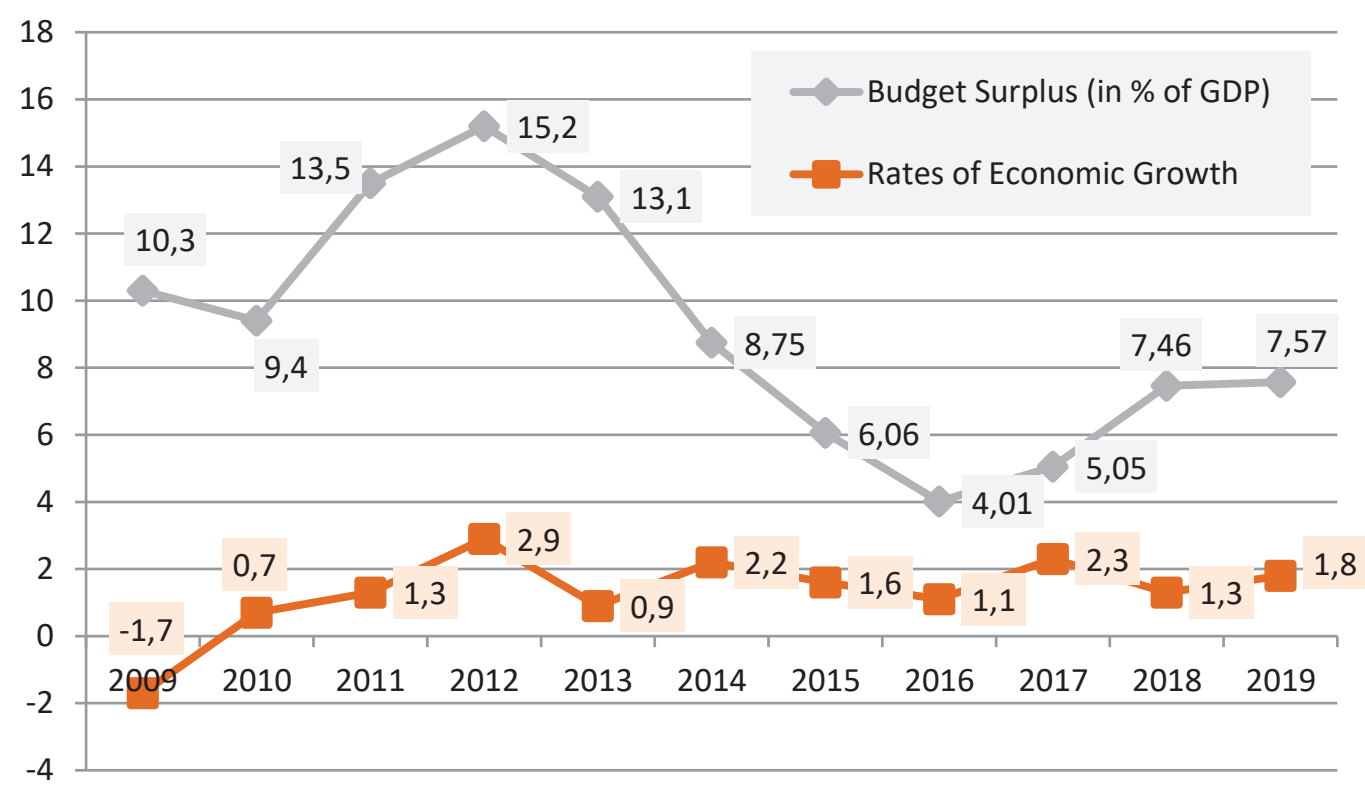

Source: Built on data from https://www.regjeringen.no/no/id4/ (accessed: 13 July 2020).

By analyzing the data presented in Figures 2 and 3, it can be concluded that overall, the countries researched show no correlation between the amount of budget deficit and the economic growth rates. Thus, for example, the most significant amount of budget surplus was recorded for Switzerland in 2009, which was accompanied by the lowest (most negative) rates of economic growth $(-2.2 \%)$. A similar situation was observed in Norway when in 2011, 2012 and 2013 , with the highest indicators of a budget surplus $(13.5 \%, 15.2 \%$ and $13.1 \%$, respectively), the country reached very moderate rates of economic growth (1.3; 2.9 and 0.9 ).

As mentioned by a number of researchers, successful consolidation largely benefited from increased export demand which alleviates the negative effects of reduced spending (for example, Perotti, 2011). It was not uncommon for consolidation to be accompanied by an increase in the economic importance of the export sectors and, subsequently, an actualization of the problem of competitiveness of other sectors in the national economy (Fatás, Summers, 2016).

In the goal of stimulating economic growth, it is often suggested that a surplus budget be used to finance the (so-called) more discretionary spending. So, for example, Reich (1999), Eisner (1998) and Baker (1998), among other authors, advocate the use of surpluses to finance government investments in education. In reality, the argument for using current (temporary) surpluses to finance a constant increase in spending has the same drawbacks as the argument in favor of a constant tax reduction (Auerbach, Gale, 2000).

Arguments according to which more discretionary spending can be financed using the current surplus are misleading. Even if it is desirable to in- 
crease the amount of government investments, this requires reducing spending for benefits or increasing taxes in the current or future periods. The argument that industrial economies have a significant amount of free resources for increasing internal spending without increasing taxes is hardly probable. Here it is appropriate to remember the recent experience of increasing VAT and introducing other taxes in Russia (Andreev, Polbin, 2018; Chelekhovsky, Khabibullin, 2018).

On the backdrop of this, the initially adopted federal budget for the current budget cycle (2020-2022) has plans for a budget surplus for the first time in Russian budgeting practice.

A number of other patterns in the Russian economy over recent years can also be noted. For example, during a growth of volume planned in the current budget cycle of a surplus and, accordingly, the Russian National Wealth Fund NWF (fig. 4), the savings "recyclable" for investments are reduced.

\section{Figure 4: Individual macroeconomic features of the federal budget of the Russian Federation (targets for 2020-2022)}

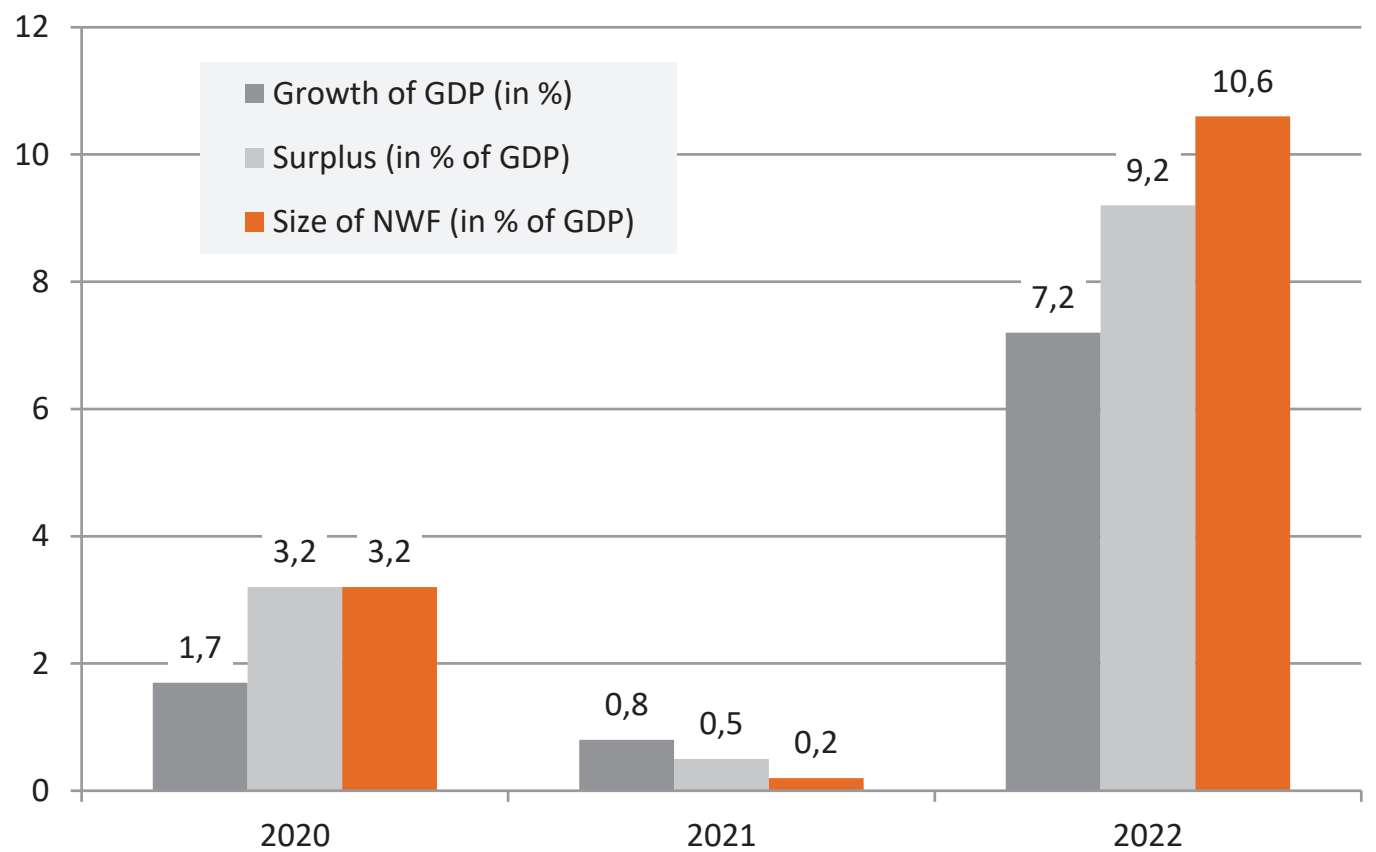

Source: Explanatory note to the Russian federal budget project. URL: https://www.minfin.ru/ru/document/ (accessed: 13 July 2020).

In connection with this, it was assumed that a number of measures focused on stimulating the process of investment activity would be taken (Moiseev, 2018). With this in mind, in early February 2020 to start the investment cycle it was decided to use funds from the NWF for inflation safe investments in the national economy at a value of 300 billion rubles yearly. The first tranche was planned to be applied in the current year already. 
It was proposed to use funds from the NWF to ensure an investment growth from $0.7 \%$ (2019 indicator) to 5\% in 2020. The increased rate of investment growth over two years (2020-2021) by more than 8.5 times (up to 6\% GDP) was to provide a growth of GDP, and when implementing this scenario in 2024, the amount of investments was to reach an indicator of 25\% GDP.

In accordance to this, the Russian government created a system for managing NWF funds, which, first of all, calls for a mechanism to minimize budget risks by ensuring the sufficient amount of NWF funds in the form of liquid financial assets which is necessary to cover lost income of the federal budget in the case of a large-scale external stress; secondly, it aims to increase the profitability of managing NWF funds when preserving the effectiveness of the "budget rules" mechanism in terms of providing stability and predictability of economic and financial conditions regardless of sharp fluctuations in the energy market.

When assessing how realistic these plans are, the following questions naturally arise. Is it better to be cautious or take risks? Is an investment of any kind beneficial to the economy? The Calvinist Léon Walras wrote that savings are tomorrow's consumption (Walras, 1879). What level of the Russian NWF is rational in terms of economic growth policy? This question remains unanswered until now.

At the same time, it should be taken into consideration that during the serious fall of the GDP in the first half of 2020, it has become clear that the political wishes of the monetary authorities (not only of Russia) can clash not only with development logic, but also with the current economic reality, since the current situation undoubtedly not only requires a substantial reexamination of economic predictions and budget indicators, it also leads to a serious restructuring of the whole global economy. However, the current situation has already negatively affected the change in size of the NWF since the start of this year. Thus, according to data from the Russian Ministry of Finance ${ }^{2}$, a nominal increase of 67.48 billion roubles occurred for January 2020; a growth of the nominal amount was also noted for February; however, if the change in the size of the NWF for JanuaryFebruary 2020 is valued in US dollars, it becomes clear that the increase was caused by the lowered exchange rate of the national currency, since converting the amount to dollars gives a reduction from the beginning of the year of 2.42 billion USD (1.18 for January and 1.24 billion USD for February). Thus, in the current situation, the degree of uncertainty in the area of managing NWF funds has significantly increased.

Despite the fact that, overall, investment spending supports economic growth, it must be remembered that in order to implement infrastructure projects, there is a significant period of time required wherein (despite the long-term benefits) a low "usefulness" of such projects for managing negative short-term changes during the current business cycle is noticed.

At the same time, the budget practice of different countries around the world has shown that there is currently no empirical evidence or appropriate

2 URL: www.minfin.ru 
theoretical generalizations about the existence of a cause-and-effect relationship between economic growth and the type of balanced state budget (deficit, surplus, "zero-based").

\section{Surplus: hoarding and taxation}

An analysis of the main macroeconomic features of the federal budget of the Russian Federation makes it possible to conclude that accumulating money in the NWF is essentially money hoarding, which, in fact, does not save them with a subsequent investment (state or private) in the national economy. Furthermore, it is possible to interpret surplus hoarding as an additional tax on the capital of businesses and household incomes.

Economic growth is always a result of investments in the economy. However, it should be said that not all investments are generative. As mentioned before, a surplus on its own does not lead to economic growth.

Neo-Keynesians support the multiplier demand idea of J.M. Keynes from 0 to 1.5 (Keynes, 2005). However, the budget multiplier can act against the budget demultiplier during a surplus budget. In other words, the hypothesis about a slowdown in demand of up to 1.5 times during a surplus budget is possible (Afanasiev, 2011). It is noted that the Ricardian multiplier is equal to zero and has a Keynesian negative effect.

Of significant interest is the research by Ramey (2019) which summarizes the results of a wide array of works, where the author concludes that assessments of the multiplier range from 0.8 to 1.5 . Based on this, it can be concluded that the tax-budget policy can support economic growth, although this effect in practice leads to very heterogeneous results (Hazlitt, 2013).

If the government collects more money than it actually spends and engages in "pure" money hoarding, then economic growth slows down. In this case, it would be advisable to reduce the tax burden in the economy.

Currently, the maximum tax burden - up to $45-55 \%$ of GDP - exists in France, Belgium, and the Netherlands. Sweden lost this "peculiar" leadership. For comparison, the tax burden indicator in Russia for 2019 equaled 46.2\%, while in the USA the value of a similar indicator was $36.6 \%$, and in Great Britain it was $30.6 \%$.

As budget practice shows, the existence of a surplus budget provides the following opportunities as well:

- more effective handling of a crisis by using fiscal incentives during a fall or in response to macroeconomic shocks;

- reducing the yield of government debt obligations by making future government loans less expensive;

- $\quad$ paying off a part of the existing government debt;

- reducing the tax burden to stimulate supply.

In connection to this, it is worth remembering A. Laffer (Laffer, Canto, 1990), who intuitively believed that taxes were "bad" for economic growth. In truth, in Russia with its tax burden of $36 \%$ of the GDP, this is yet to be a topic of discussion about the importance of the Laffer curve in terms of a possi- 
ble slowing down of national economy development. The Laffer curve is more an intellectual exercise, since empirical and statistical evidence of its existence has until now yet to be presented.

However, it can be used to illustrate the events taking place in the Russian economy. If the VAT rate increased from $18 \%$ to $20 \%$ to supposedly cover the deficit of the Russian pension fund, then why was a budget surplus formed? Where is the validity for the measures of economic policy being implemented? Supporters of using a surplus to reduce taxes believe that it is necessary to reduce the burden and to balance the proportions of the taxation of businesses and households. However, no consensus has yet to be reached about exactly what kind(s) of tax(es) should be reduced.

A very important question for any national economy where a surplus budget is recorded is the decision about the areas where it will be used (Haffert, Mehrtens, 2015). Analysis shows that in all countries with a long-term period of a surplus budget, measures for a substantial reduction in taxes were taken in the first years the surplus was recorded. Furthermore, the existence of a surplus in itself, apparently, is evidence of the fact that economic agents are overloaded with taxes and deserve tax breaks.

Despite the fact that other authors (e.g., Alesina, 2000) consider the argument in favor of a temporary tax reduction in relation to budgetary practice in individual countries to be very weak (in terms of economic theory), the reduction of taxes has, to a certain degree, become a fairly successful economic strategy for increasing the competitiveness of countries with a long-term surplus budget.

Being (for the most part) small open economies, these countries could benefit from international tax competition, since the correlation between lost revenue during the current tax base and additional revenue gained from increasing the tax base by attracting new investors has become especially favorable (Genschel, Schwarz, 2011).

The macroeconomic approach to the impact of the fiscal policy on economics often ignores its redistributive effects. Types of redistribution which consider standard macroeconomic models of fiscal policy give some kind of visible effect over generations. It is natural that changing the fiscal regime, which leads to establishing a new "surplus regime", is as a rule accompanied by obligations to use a surplus as compensation for reducing the tax burden. This "regime" approach should have consequences not only for analyzing a surplus budget but also for the continued (closer) study of budget policy.

The conditions laid out above bring to attention specific historical conditions in which a tax budget policy was carried out and place in doubt the validity of broad generalizations, including the prediction of a constant "deficit". In particular, such an approach shows the limits of the fiscal policy concept established in the world (Blinder, 2016). This is especially important in cases where the prevailing fiscal policy regimes face difficulties and the configuration of fiscal interests starts to change.

One of the last examples of such a change in the configuration of fiscal interests is undoubtedly the reaction to the 2008 financial crisis (the economic and budget consequences of the current force majeure conditions cannot currently 
be calculated due to the uncertainty of the period of "freezing" the economy). Many studies dedicated to this crisis are focused on more pressing issues of fighting deficits, balancing financial markets and reviving economic growth.

According to this approach, it can be asserted that the long-term effects of various kinds of budget policies are just as important as their immediate effects. It is clear that the decisions made in response to the 2008 crisis determined the direction of the budget policy for many years ahead. However, it is not practically possible to predict exactly what specific effect will come from implementing the various options.

During future studies, it is advisable to analyze the dependencies on the chosen trajectory in the fiscal policy on a much more systematic scale, in other words, to not only identify them ex-post, but to also foresee them ex-ante.

The next, highly interesting fact is the gaining of remarkable value through budget rules when reducing the tax burden. Instead of being a legitimate reason for saving surpluses, the main goal of budget rules is to influence the use of surpluses and apply them for adjusting the whole tax system. This is especially clear in the case of establishing ceilings on spending, which prohibit the use of unexpected revenue for anything other than reducing taxes or paying off the state debt.

One curious condition is that the area of use and principles of forming a surplus significantly impact its preservation. Only countries which used their surplus for reducing taxes were able to maintain it; likewise, only countries which created a surplus by reducing spending were able to fulfill these commitments. At the same time, it should be understood that as a result of mass reductions in spending, economic agents pay more or less the same taxes as before, but they receive significantly less government services.

The argument in favor of a constant tax reduction should ultimately be based on two grounds: first, the conditions that the spending of economic agents is either constantly decreasing or their constant decrease is expected; second, that the rate of growth of the national economy is constantly increasing for "exogenous" reasons, therefore lower tax rates are to generate higher revenue.

At the same time, it is advisable to form and introduce into budgeting practice budget rules regarding a balanced budget, debt, spending and revenue, with the obligation to observe them strictly. It is possible that it is the current, unique financial and macroeconomic difficulties experienced by the economies of various countries, including the Russian Federation, due to the epidemiological factor which can become the prerequisites for forming a "new fiscal regime".

\section{Acknowledgement}

The authors are grateful to the following professors for discussing this paper: Prof. Charles Wyplosz (IURM, Geneva), Prof. Jacques Sapir (CEMI, Paris) and Prof. Anton Moiseev (IEF RAS, Moscow). 


\section{REFERENCES}

1. Afanasiev, M.P. (2011). "General Theory" by J. M. Keynes: Origins and Future (To the 75th Anniversary of the First Publication). Financial Journal, no 1, pp. 151-156 (in Russian).

2. Alesina, A. (2000). The Political Economy of the Budget Surplus in the U.S. NBER, Working Paper 7894.

3. Alesina, A. \& Ardagna, S. (2009). Large Changes in Fiscal Policy. Taxes Versus Spending. NBER, Working Paper 15438.

4. Alesina, A., Favero, C. \& Giavazzi, F. (2019). Effects of Austerity: Expenditures- and TaxBased Approaches. Journal of Economic Perspectives, vol. 33, no 2, pp. 141-162.

5. Alibegović, D., Hodžić, S. \& Bečić, E. (2019). The Level of Fiscal Autonomy: Evidence from Croatia, Serbia and Bosnia and Herzegovina. NISPAcee Journal of Public Administration and Policy, vol. 12, no 1, pp. 91-112.

6. Andreev, M.Yu. \& Polbin, A.V. (2018). Influence of Fiscal Policy on Macroeconomic Indicators in DSGE Models. Scientific-Research Financial Institute. Financial Journal, no 3, vol. 43, pp. 21-33. (in Russain).

7. Androniceanu, A., Gherghina, R. \& Ciobanasu, M. (2019). The interdependence between fiscal public policies and tax evasion. Administratie si Management Public, no 32, pp. 32-41.

8. Auerbach, A.J. \& Gale, W.G. (2000). Perspectives on the Budget Surplus. Working Paper 7837. National Bureau of Economic Research. Cambridge (NBER Macroeconomics Journal, Cambridge, MA.).

9. Baker, D. (1998). The Great Surplus Debate: Invest it? The American Spectator, May-June, pp. 83-86.

10. Barro, R.J. (1979). On the Determination of Public Dept. Journal of Political Economy, vol. 87, no 5, pp. 940-971.

11. Barro, R.J. (1989). The Ricardian Approach to Budget Deficits? Journal of Economic Perspectives, vol. 3, no 2, pp. 37-54.

12. Blinder, A.S. (2016). Fiscal Policy Reconsidered. Policy Brief Series (Hamilton Project) 2016-5.

13. Buchanan, J. M. \& Wagner, R.E. (1977). Democracy in Deficit: The Political Legacy of Lord Keynes. New York: Academic Press.

14. Budina, N., Kinda, T., Schaechter, A. \& Weber, A. (2012). Fiscal Rules at a Glance: Country Details from a New Dataset. IMF Working Paper 12/273.

15. Chelekhovsky, A.N. \& Khabibullin, R.A. (2018). Fiscal Policy Under the Threat of a Double Crisis. Journal of Economic Theory, vol. 15, no 3, pp. 429-441 (in Russian).

16. Cohen-Setton, J., Gornostay, E. \& Ladreit, C. (2019). Aggregate of Budget Stimulus: Evidence from the Large Fiscal Expansions Database. Peterson Institute for International Economics, Working Paper 19-12.

17. Dadashev, A.Z. (2017). On Improving Tax Policy and Fiscal Castling. Finance, no 9, pp. 24-28 (in Russian).

18. Eisner, R. (1998). The Great Surplus Debate: Invest it? The American Spectator, May-June, pp. 83-86.

19. Emigh, R. (1997). The Power of Negative Thinking: The Use of Negative Case Methodology in the Development of Sociological Theory. Theory and Society, no 26, pp. 649-684.

20. Fatás, A. \& Summers, L. (2016). The Permanent Effects of Fiscal Consolidation, NBER, Working Paper 22374. 
21. Genschel, P. \& Schwarz, P. (2011). Tax Competition: A Literature Review, Socio-Economic Review, vol. 9, no 2, pp. 339-370.

22. Guichard, S., Kennedy, M., Wurzel, E. \& André, C. (2007). What Affects Fiscal Consolidation? Some Evidence from OECD-Countries, OECD Economics Department, Working Paper 553.

23. Haffert, L. (2015). Permanent Budget Surplus as a Fiscal Regime, EUI, Working Paper MWP 2015/10.

24. Haffert, L. \& Mehrtens P. (2015). From Austerity to Expansion? Consolidation, Budget Surpluses, and the Decline of Fiscal Capacity, Politics \& Society, Online First. Available at: DOI: 10.1177/0032329214556276 (accessed: 13 July 2020).

25. Hazlitt, H. (ed.) (2013). The Critics of Keynesian Economics. N.Y. FEE.

26. Laffer, A.B. \& Canto, V.A. (1990). Monetary Policy, Taxation, and International Investment Strategy. N.-Y., Quorum Books.

27. Lewis, T. (2003). In the Long Run We're All Dead: The Canadian Turn to Fiscal Restraint. Vancouver: UBC Press.

28. Lucas, Jr., Robert, E. \& Stokey, N.L. (1983). Optimal Fiscal and Monetary Policy in an Economy Without Capital, Journal of Monetary Economics, no 12, pp. 55-94.

29. Mehrtens, P. (2014). Staatsschulden und Staatstätigkeit: Zur Transformation der politischen Ökonomie Schwedens. Frankfurt: Campus.

30. Moiseev, A.K. (2018). Analysis of Modern Approaches to Stimulating the Development of the National Economy Using Financial Instruments. Economic Strategy, vol. 21, no 8 (166), pp. 24-29.

31. Perotti, R. (2011). The "Austerity Myth": Gain Without Pain? NBER, Working Paper 17571.

32. Pigou, A.C. (1921). The Political Economy of War. London: MacMillan.

33. Pigou, A.C. (1960). A Study in Public Finance. London: MacMillan.

34. Ramey, V. (2019). Ten Years after the Financial Crisis; What Have We Learned from the Renaissance in Fiscal Research? Journal of Economic Perspectives, vol. 33, no 2, pp. 89-114.

35. Reich, R. (1999). The Other Surplus Option. Journal of Economic Perspectives, vol. 5, no 3, pp. 61-69.

36. Schwartz, H. (1994). Small States in Big Trouble: State Reorganization in Australia, Denmark, New Zealand, and Sweden in the 1980s. World Politics, vol. 46, no 4, pp. 527-555.

37. Serkov, L.A. (2017). Modeling of the Search for Monetary and Fiscal Policies that Are Resistant to Uncertainties in Their Cooperative Interaction. Economic Analysis: Theory and Practice, vol. 16, no 10 (469), pp. 1972-2988 (in Russian).

38. Stiglitz, J.E., Walsh, C.E. \& Lafay J.-D. (2010). Principes d'Économie Moderne, 3nd ed., Bruxelles: De boeck.

39. Tille, C. (2019). The "Burden" of Swiss Public Debt: Lessons from Research and Options for the Future. IHEID, Working Papers 14-2019.

40. Von Hagen, J., Hallett, A.H. \& Strauch, R. (2002). Budgetary Consolidation in Europe: Quality, Economic Conditions, and Persistence. Journal of the Japanese and International Economies, no 16, pp. 512-535.

41. Wagschal, U. \& Wenzelburger, G. (2008). Roads to Success: Budget Consolidations in OECD Countries. Journal of Public Policy, vol. 28, no 3, pp. 309-339.

42. Walras, L. (1879). Éléments d'Économie Politique Pure ou Théorie de la Richesse Sociale, Lausanne: Corbaz. 